Louisiana State University

LSU Digital Commons

Faculty Publications

Department of Geography \& Anthropology

2018

\title{
Conceived versus Lived Social Spaces and the Transformation of the Morro da Providência Favela of Rio de Janeiro Since 2008
}

Jamie Worms

Smith College, jworms@smith.edu

Andrew Sluyter

Louisiana State University, asluyter@lsu.edu

Follow this and additional works at: https://digitalcommons.lsu.edu/geoanth_pubs

Part of the Anthropology Commons, and the Geography Commons

\section{Recommended Citation}

Jamie Worms and A. Sluyter. 2018. Conceived versus Lived Social Spaces and the Transformation of the Morro da Providência Favela of Rio de Janeiro Since 2008. The Latin Americanist 62: 545-67

This Article is brought to you for free and open access by the Department of Geography \& Anthropology at LSU Digital Commons. It has been accepted for inclusion in Faculty Publications by an authorized administrator of LSU Digital Commons. For more information, please contact gcoste1@lsu.edu. 


\title{
Conceived Versus Lived Social Spaces and the Transformation of the Morro da Providência FAVEla of Rio de JANEIRO Since 2008
}

\author{
Jamie L. Worms \\ Latin American and Latino/a Studies \\ Smith College \\ Andrew Sluyter \\ Geography and Anthropology \\ Louisiana State University
}

\begin{abstract}
In anticipation of the 2014 World Cup and the 2016 Olympic Games, Rio de Janeiro initiated several urban infrastructure projects including Porto Maravilha, Morar Carioca, and the Units of Police Pacification (UPP) program. Starting in 2008, one aspect of that effort involved bringing favelas, irregular and unplanned neighborhoods, under the control of centralized urban planning. However, rather than consult the residents to align infrastructure planning with the needs of the community, the planners imposed projects such as a cable car and a funicular tram. The authors use mental maps drawn by the residents of the Morro da Providência favela to uncover five main themes related to that process: public space, sanitation, access to food, transportation, and fear. The method reveals the residents' perspectives on the disconnect between the conceived social space of urban planners and the lived social space of everyday life, and thereby, how the infrastructure projects failed the needs of the favela community.
\end{abstract}

Rio de Janeiro, the second most populous city in Brazil and the country's former capital, has a long history of inequitable social relations that top-down planning strategies have reproduced and reinforced. Inequities resulting from colonial ideologies and practices concerning land and slave ownership that favored a minority of privileged elite, continue to influence the racial and class hierarchies present in Brazilian society today (Larkins 2014; Arias 2008; Mitchell \& Reiter 2010, Perlman 2010, Leeds 1996; Perlman 1978). Today, nearly 60 percent of the residents of Rio de Janeiro are Afro-Brazilian (Williamson \& Hora 2012). As such, Rio de Janeiro has evolved into a divided city where pockets of favelas have developed amid the legal city (asfalto) visually distinguishing the poor from the rich. 
Figure 1. The location of the port area within Rio de Janeiro and the Morro da Providência favela (red outline) within the Porto Maravilha Project zone (blue outline).

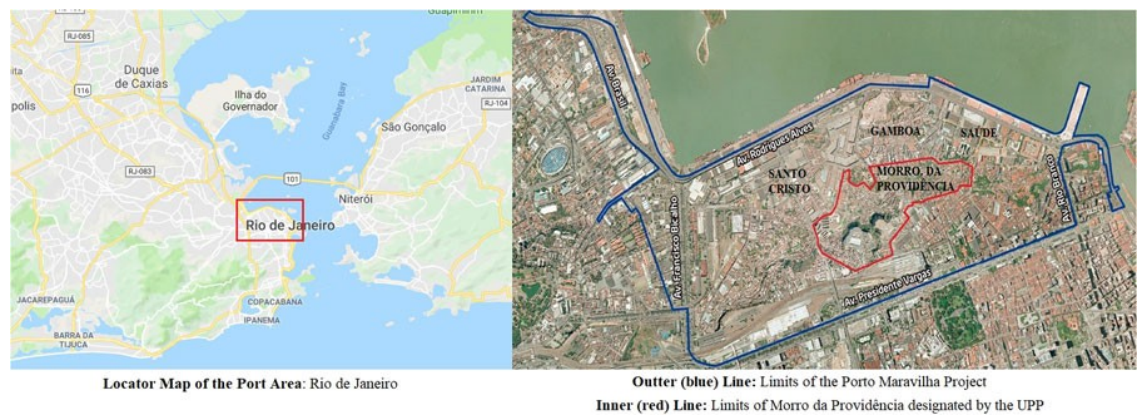

Source: Google base map modified by the authors, 2018.

Reinforced by labels, colloquialisms, and racial lines, there is a clear distinction between where the formal city ends, and the informal city begins.

Favelas are distinct, irregular, unplanned communities in Brazil (Williamson 2017; Novaes 2014). Long derived as "slums," the domain of the poor and criminal organizations, favelas are characterized by selfhelp construction methods and inadequate access to public services. In the face of racism, marginalization, and stigmatization, favela communities have etched themselves into the permanent landscape of Brazil and have simultaneously remained beyond the purview of the city's government since their founding in the late nineteenth century.

Policies initiated in 2008 in anticipation of the 2014 World Cup and 2016 Olympic Games mega-events, including the implementation of Units of Police Pacification (UPP) and various infrastructure projects, have attempted to bring favelas under the control of centralized urban planning (Oosterbaan \& van Wijk 2015). That effort challenged the local control of favela communities, particularly that of the dominant drug trafficking gangs. The resulting social and physical infrastructure projects in favelas, introduction of businesses, and entry of tourists sought to integrate favelas and their residents into the broader urban planning framework of Rio de Janeiro. However, the mega-event planners rarely consulted favela residents. In talking with the residents during research for this paper, the authors consistently found that while the residents both welcomed and recognized the importance of the infrastructure improvements, they resented the general lack of attention to local concerns and priorities.

The Morro da Providência favela, located in the port area and subject to two government development programs, the Porto Maravilha Urban Operation and the Morar Carioca Program, provides an opportunity to research those tensions between local and centralized control over marginalized urban social spaces (Figure 1). The Porto Maravilha Urban Operation, designed by the Porto Novo Consortium, forms part of "the country's first 
public-private partnership (PPP) for urban revitalization" and one of the most "expensive and ambitious" urban infrastructure projects associated with the World Cup and Olympic Games, nearing R $\$ 8$ billion (US 4.1 billion) over the course of fifteen years (Odebrecht 2011; Antunes 2013, 355; CDURP 2017). The Morar Carioca Program is part of the Municipal Secretary of Housing (SMH) and falls under the Federal Growth Acceleration Program (PAC). PAC aims to "formalize" all the city's favelas by 2020 and spent nearly R $\$ 27.2$ billion (US 13.5 billion) between 2007 and 2011 alone (Neele 2012). The planners pledged to erect a state-of-the-art cable car (teleférico), build a funicular tram, and widen roads in Morro da Providência to transform the community "into a new tourist attraction for Rio" during the mega-events of 2014-2016, largely ignoring the longterms needs of the residents (Williamson \& Hora 2012; Prefeitura do Rio de Janeiro 2012, 156).

This research used a mixed method approach that combined formal and informal interviews and participant observation with mental mapping to understand how such inequitable social relations are often "hidden in the order of space," resulting in a marked disconnect between the conceived space of urban planners and the lived space of everyday life (Lefebvre 1991, 289). For the purpose of this paper, mental mapping is understood as a cognitive representation of a given place without cartographic necessities like scale or direction. The authors believe that everyone has the capacity for mental mapping and its accessibility is precisely the reason it is used as the primary methodology for this research. Mental mapping combines the use of memory and material culture to construct individual representations that draw out differences in space (Soini 2001; Potter 2011; Tolia-Kelly 2004; Rose 2003; Hayden 1995). Furthermore, using an analysis by Frederic Jameson, mental mapping is not mimetic; mental mapping is a representation, full of distortions and omissions of an individual's personal experience, whether real or imagined (Roberts 2000, 141). In other words, mental mapping is a technique by which individuals make sense of their socio-political environments.

Social behavior is often structured by territory. In many instances, people primarily act within spaces designed by elites such as architects, planners, and developers (Elden 2004; Lefebvre 2009; Agnew 2011). In doing so they reproduce the relations of social power and dominant discourses of identity represented within the putatively "passive receptacle" of space (Lefebvre 1991, 90). Territories also structure social behavior. As such, "one of the consistent ways to limit the economic and political rights of groups has been to constrain social reproduction by limiting access to space" (Hayden 1995, 22). For this reason, mental maps drawn by local residents are important because they reveal how the residents understand, feel about, and live in the spaces represented on the formal maps of the central planning authorities. Mental maps thereby help to illuminate the tensions, conflicts, and relations between conceived space and lived space. After an introduction to the favelas of Rio de Janeiro and a section that details the 
method of mental mapping, an analysis of mental maps produced in 2013 by sixty residents of Morro da Providência reveals their perspective on how their long marginalized urban space was undergoing intense transformation as the government of Rio de Janeiro prepared for the 2014-2016 mega-events.

\section{The Favelas of Rio De Janeiro}

As evident from colonial times, the deeply embedded racial prejudice and social marginalization that divides Brazilians has helped to construct the "favela problem," which conceives favela spaces and their residents as a hindrance to urban development due to their imagined disease, poverty, lack of order, and violence (Larkins 2015, 7). Favelas emerged in the late nineteenth century, built on vacant land by homeless demobilized soldiers and former slaves, with Morro da Providência the first formally recognized favela of them all. During the authoritarian Estado Novo government of 1937-1945, "favelas were seen in the political arena, among public and health officials, and in the press and non-favela communities as synonymous with violence, immorality, and disease" (Vargas 2003, 39). Planners considered favelas to be "aberrations within the modern city, refused to list them on city maps, and slated them for removal" (Arias 2006, 23). Due to their lack of land titles and proximity to areas of prime real estate, favelas were constantly threatened by "public evictions, use of military and police force, and unexplained night violence and fires" (Anthony 2013, 345). The military dictatorship of 1964-1985 made favela eradication a national priority and ordered hundreds of favelas razed and hundreds of thousands of residents relocated to the northern and western margins of the city. Nonetheless, during the industrialization boom of the 1960s and 1970s, many rural Brazilians moved to Rio de Janeiro and took up residence in favelas that continued to grow in area, number, and population (Anthony 2013, 347).

The inhabitants of favelas had to create their own infrastructures through Residents Associations and a special brand of improvised ingenuity referred to in Portuguese as gambiarra (Williamson 2017, 219). Residents used unregulated construction methods and unauthorized access to electricity, water, sewage, and cable service to provide what government and utility companies would not. Major infrastructure improvements such as road paving, soccer fields, medical clinics, water mains, electrical substations, and schools relied on the patronage of politicians seeking voting blocks and the charity of the Catholic Church. In the 1980s, drug gangs seeking urban bases assumed the patronage role, providing security and economic development in exchange for a refuge beyond the purview of the police (Goldstein 2003, 200; Arias 2004, 1; Anthony 2013, 347; Larkins 2014, 33).

By the early twenty-first century, then, favelas had become a viable, if difficult, long-term residential option for generations of low-income 
residents. According to the 2010 Census, 11.25 million people, or 6 percent of the Brazilian population then lived in 6,239 favelas throughout Brazil (Instituto Brasileiro de Geografia e Estatística 2010). Nearly 42 percent of all favela residences were concentrated in Rio de Janeiro and nearby São Paulo (Spinetto 2014). Precise population statistics for individual favelas such as Moro da Providência remain elusive. However, the most accepted estimates claim that while São Paulo has more favela clusters than Rio de Janeiro, the favela population in Rio is larger. In Rio, there are nearly 1.4 million favela inhabitants who comprise 22 percent of population (Instituto Brasileiro de Geografia e Estatística 2010; Galdo, 2011; Williamson 2017).

Despite their contentious history and social marginalization, favela residents comprise a significant economic group. They include the majority of informal sector workers, who are prevalent in all aspects of the economy and necessary to the functioning of Rio de Janeiro. And they include, increasingly, a large proportion of middleclass workers in the formal sector. Recent studies indicate that 65 percent of favela residents constitute new members of the middle class, including barbers, tour guides, maids, domestic workers, police officers, daycare workers, taxi drivers, waiters, and construction workers (Carneiro 2014). The resulting household income ensured that, by the early twenty-first century, many favela homes had running water, electricity, refrigerators, televisions, and Internet. Meanwhile, public infrastructure beyond the home-such as lighting, drainage, sewers, garbage removal, parks, and streets - remained highly irregular and poorly maintained.

As part of the planning for the mega-events of 2014-2016, Rio de Janeiro adopted what Larkins $(2014,140)$ refers to as "the Olympic exception," the putative ability of a city to capitalize on its position as the host of a prestigious global event such as the Olympics or World Cup to transform itself "with a speed and tenor" that would otherwise be "financially and politically impossible." In some favelas, this Olympic exception has resulted in rapid land privatization, real-estate inflation, militarization, numerous cases of human rights abuse, and over 170,000 forced removals to facilitate centrally planned PPP infrastructure projects (Gaffney 2016). Favela Complexo de Alemão received an elaborate teleférico system. Favela Santa Marta acquired a funicular tram and tourist maps. In favela Babilônia, a project paved pathways, staircases, and plazas. A new elevator in favela Cantagalo allowed residents to more easily ascend from street level to their hillside favela. And, in favela Morro da Providencia, the subject of this research, the state proposed building a teleférico, a funicular tram, and other infrastructure projects including a highly-anticipated sports complex.

\section{Mental Mapping}

Mental mapping, also called cognitive mapping, originated in the field of behavioral geography but soon became adopted in urban planning, anthropology, sociology, psychology, and other fields (Moore \& Golledge 
1976). In fact, the first study on cognitive maps and geographic perception is traced to Charles Trowbridge's "On Fundamental Methods of Orientation and Imaginary Maps" (1913), although Edward Tolman popularly receives credit for coining the term "cognitive map" in "Cognitive Maps in Rats and Men" (1948) (da Vinha 2012; Kitchin 2002; Mark 1999; Golledge 1997; Bell 1996; Saarinen 1987; Tolman 1948). However, it was not until Kevin Lynch's publication “The Image and the City" (1960) that there was a renewed interest in cognitive maps. Lynch went on to analyze the relationship between the use and perception of urban space and understood mental maps as a reflection of the individual's interaction with the environment as well as an endowment of the use and meaning of space (Lynch 1960).

For the purpose of this paper, the most essential meaning of mental mapping is to understand social space as perceived by those who live in it, in stark contrast to the formal maps of those who conceive urban spaces. Mental mapping utilizes the innate ability of people to produce cognitive images of an environment, often retained in long-term memory (Pocock 1976; Soini 2001). It thereby has the potential to democratize map making and redistribute social power away from urban planners and developers toward individuals and residents (Harley 1989, 1991; Monmonier 1991; Wood 1992; Aberley 1993; Perkins 2003, 344). Moreover, when used in research on a community, the mapping process facilitates open-ended dialogue about social space between the researcher and the residents. Elaborations of mental mapping termed community, local, counter, or participatory mapping have thereby become valuable tools to empower residents to produce "visual depictions of an area that record and promote social, environmental and cultural resources" (Fahy \& Cinnéide 2009, 168; Elwood \& Leitner 1998, 2003; Sieber 2001; Elwood 2002; Kyem 2004; Peluso 1995; Mollett 2013).

The mental mapping research with residents of Morro da Providência sought to understand the transformation of social space through the centrally-planned, PPP infrastructure projects in relation to the way residents actually lived in that space. The project engaged residents in an opportunity to think critically and spatially about their social space and empower them to propose alternatives to the PPP projects that better fit into the ways in which they lived in that social space. Participant observation and formal and informal interviews provided the context for the mental mapping sessions. Of the total of sixty mental maps collected over five months in spring 2013, women produced twenty-six of them and men thirty-four. All sixty of the participants were aged 18-70 at the time. Potential participants were approached while they were sitting or walking alone through the community, employing theoretical sampling to ensure variation in age and gender within the sample and altering the location to preclude spatial saturation (Crang \& Cook 2007, 15, 48; DeWalt \& DeWalt 2002,81 ). Interviews proceeded only on an individual basis because with groups of two or more, people become hesitant to draw maps, claiming 
poor drawing skills to avoid the unfamiliar task. In addition, participants answered a set of standard interview questions to ensure consistency in the diverse sample.

To understand the transformation of lived social space over time, we asked residents to draw from memory a map of their community that indicated places of importance: for example, where they lived, shopped, spent leisure time, and entered and exited the favela. Participants used a blue pen to represent places in the community that they remembered from the past, whether or not they were extant or not, and that were therefore significant in their mental map of the favela. They next used an orange pen to represent their present lived space. Next, to understand how residents desired social space to change in future, we informed participants that the city planned to transform the favela with the teleférico and other projects, and we asked them whether they had seen the plans or been consulted in the planning process. An overwhelming majority of the community had not even heard much about the planned projects let alone been consulted. We therefore asked them to suggest their own infrastructure plans, using a green pen to draw them onto the same map they had produced with the blue and orange pens. While this project could have employed a touchscreen tablet computer to facilitate and manage the mapping, the authors chose ordinary equipment such as pen and paper to ensure the project's accessibility and global replicability.

As participants engaged in drawing their mental maps, rapport developed and resulted in open-ended dialog about social space and other aspects of their lives. We took detailed notes. Some participants were illiterate, and we labeled or otherwise annotated their maps at their direction in Portuguese and/or English. Others labeled and annotated their own maps. Some used a single sheet or paper, others several. Some overlaid their blue, orange, and green maps. Others drew them separately, sideby-side or on separate sheets of paper. And yet others would draw only one or two of the suggested maps. That process resulted in a rich, detailed understanding of the lived space of Morro da Providência and context for subsequent content analysis of the mental maps. As opposed to relying on the abstract, conceived space designed by the elite, this project focused on the representational lived space created and used by the residents.

\section{Mapping Lived Social Space}

The resulting maps represent the transformation of social space over time. A single article allows for presentation and detailed discussion of only a few representative examples of the sixty mental maps, some drawn on more than one sheet of paper. The full corpus of mental maps is available to readers online, however: www.blinded.edu. This section presents some examples of the major styles of mental map the participants produced and the five most prevalent themes.

The first example, by a 34-year-old named Bruno (all names are pseudonyms to preserve anonymity), illustrates the general style of many 
Figure 2. Bruno's map sequence, on a single sheet of paper, 2013.



of the maps. It shows the curve of the street he lives on (Figure 2). In the blue map, which depicts the past, the drug traffickers occupied the corner and used it as a boca de fumo, a point of drug sale, which Bruno identified by drawing a pistol on the blue map. Since the establishment of the UPP, the traffickers have been operating much more discreetly from within their homes. As such, Bruno drew children playing with a soccer ball and a kite in the orange map, which depicts the present. He also drew one of the support towers of the new teleférico, still under construction at that time, but promising easier access to the favela in future. At the same time, he indicated long-ignored infrastructure problems: potholes (buracos) in the street and the open sewer contributing to pools of water under the teleférico support towers. To represent a desired, future social space, Bruno drew the green map: a street without potholes, an improved sewer system (sistema de esgoto), and a community soccer field. He also annotated in a mix of English and Portuguese, but did not draw, a desire for community gardens and public schools and health care.

Such suggestions for social programs often appear as words or lists on the mental maps because they are difficult to represent spatially. In fact, some drawings produced by the residents were completely aspatial. For example, Renata, 62-years-old, recited the places important to her aloud as she jotted down an $\mathrm{X}$ in a random location to represent each place. 
Figure 3. Leonel's map of an idealized past, 2013.

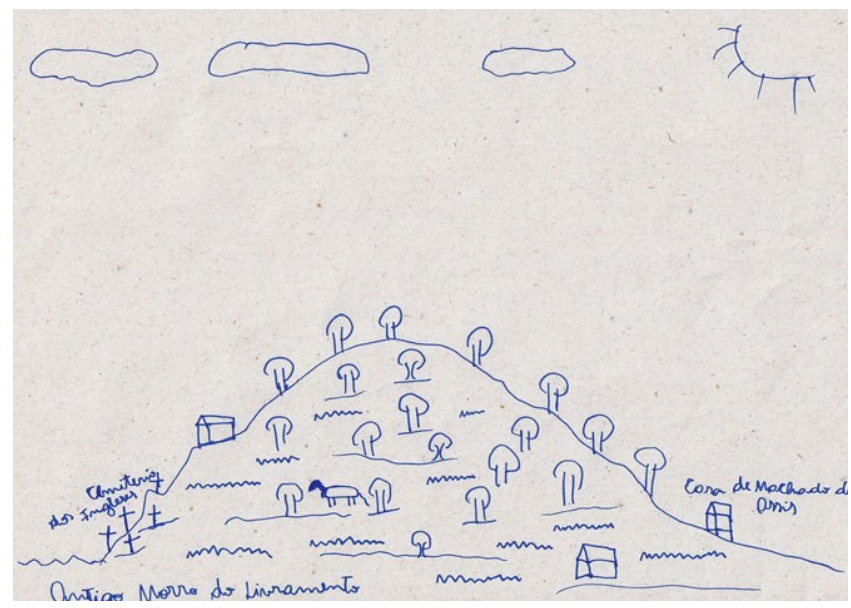

Renata's places of importance included, "the pharmacy, the school, the nursery school, the hospital, the post office, and the health clinic." While entirely aspatial drawings were uncommon, all of the mental maps had aspatial components that participants simply listed in writing or verbally, in which case we added them as they spoke. The mapping process, in that way, served as a catalyst for an open-ended discussion about social space. Other examples of the types of infrastructure improvements the mapping process evoked as a list included structural reinforcement of homes built on steep slopes, pavement of roads, repair of sewage lines, public lighting, improved schools and health services, playing fields, and parks.

Five major themes emerged including open public spaces, sanitation, access to food, transportation, and fear. The first theme we will discuss relates to open public spaces which twenty-one (35 percent) of the participants emphasized on their maps. Leonel, age 18, for example, drew his sequence of maps to represent the reduction over time in open space and his desire for its future expansion. He insisted that he receive three separate pieces of paper so that he could draw all three time periods accurately from the oblique, human perspective of lived space rather than the plan view used in the formal maps and plans of conceived space (Figures 3-5). For the past, he depicted an idealized rural landscape with open pastures dotted with scattered trees. Leonel made mention of the British Cemetery (Cemitério dos Ingleses) and the former house of the esteemed Brazilian novelist, Machado de Assis. For the present, he drew the community with many houses in close proximity to one another and connected by a series of pathways and electrical wires. Landmarks such as the Central Station's iconic clock tower, the water tower, the Igreja Nossa Senhora da Penha church, the Capela das Almas chapel, and the Casa Amarela NGO community center mark the skyline. Local names of neighborhoods, 
Figure 4. Leonel's map of the present, 2013.

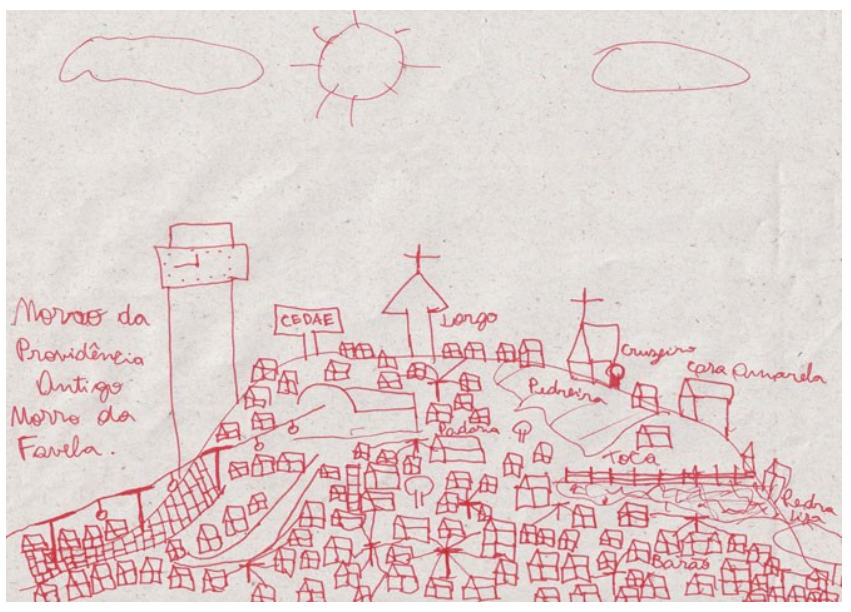

Figure 5. Leonel's map of the desired future, 2013.

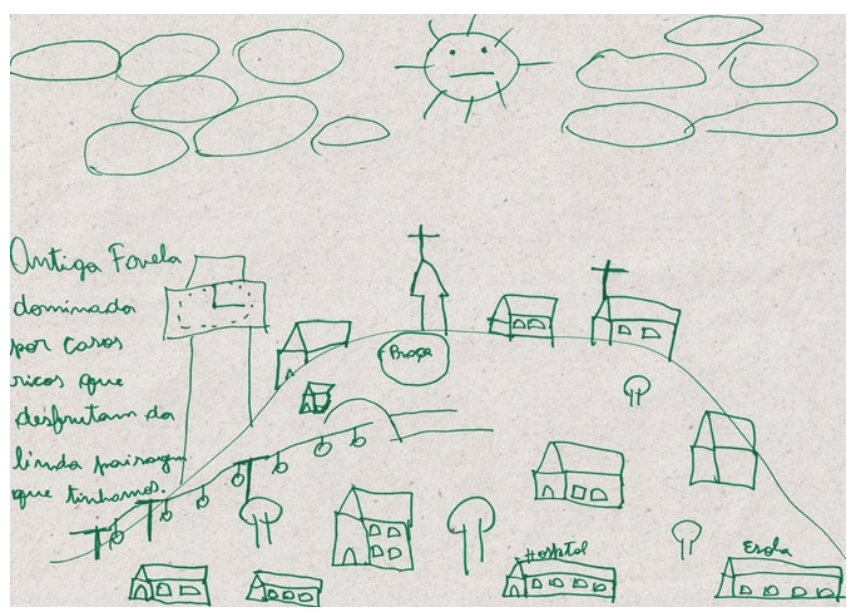

known only to residents, appear among the buildings: Largo, Cruzeiro, Pedreira, Toca, Barão, Pedra Lisa. The teleférico climbs the left-hand slope even though it is still not operational. Despite attention to detail, he did not include open, public spaces because, he said, "there are none." His map of a desired future combines aspects of the past and present, including the teleférico, the church, chapel, clock tower, and water tower. But he reduces the density of housing by razing the many small houses and replacing them with a few mansions (casas ricas) set among open fields with scattered trees, evocative of the pastures of the rural past, and a public plaza (praça) in front of the church to indicate the vastly expanded open space. With a melancholy sun in the sky, Leonel explains, that "the 
Figure 6. Omar's map, 2013.

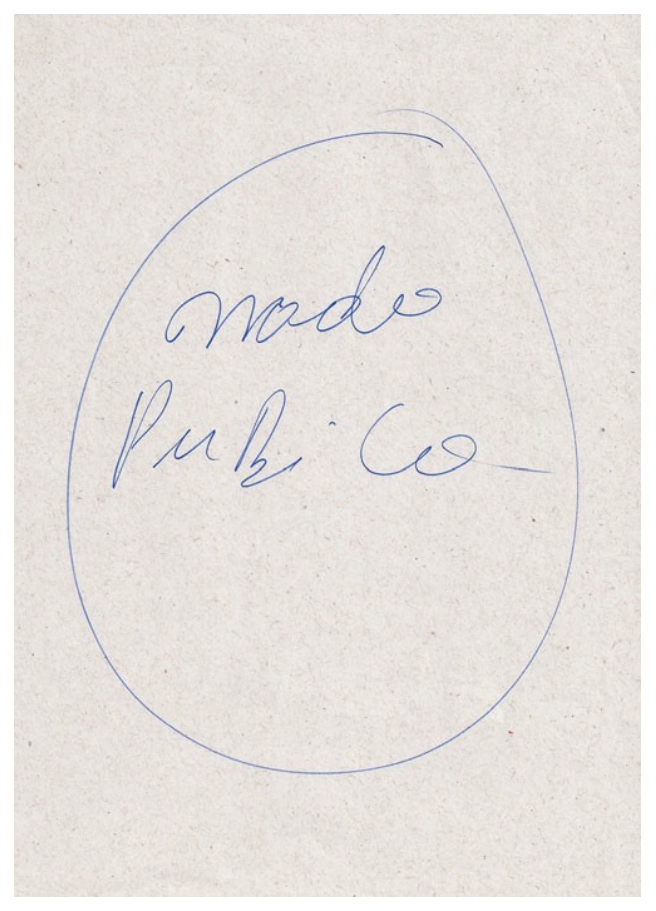

historic favela will be dominated by rich houses that will enjoy the beautiful landscape view that we once had" (translated by authors).

Other participants emphasized more specific aspects of the lack of open, public, and leisure spaces in the favela. Construction of the teleférico station obliterated Praça Américo Brum, the largest plaza (praça) in the favela. Omar's disgust at the loss resulted in his map, a simple circle to represent the favela and the words, "Nada Publico," meaning "Nothing Public" (Figure 6). Without any public spaces, he and many others explained that adults must now gather in bars while children are resigned to playing in the alleyways and rooftops for their two most popular outdoor leisure activities: soccer and kite flying (Figure 7). Shortly before the research took place, two children had fallen from a rooftop, both suffering broken limbs, while flying their kites, as depicted in Luís's map (Figure 8).

The second theme involves sanitation and focuses on garbage and sewage. Twenty-seven percent of the participants expressed a desire to see improvements in garbage removal and sewers. Currently, although trash is scheduled to be collected three times per week, garbage bins (caixas de lixo) are small and few, and collection is, in reality, irregular and partial. Without enough garbage bins, many participants throw their trash on the ground, over the edge of the cliff, or leave it for the pigs to eat (Figure 9). Simone, age 66, desired "at least, one garbage bin on every 
The Latin Americanist, December 2018

Figure 7. Children flying kites from a rooftop, 2013.



Source: the authors.

Figure 8. Luís's map, 2013.

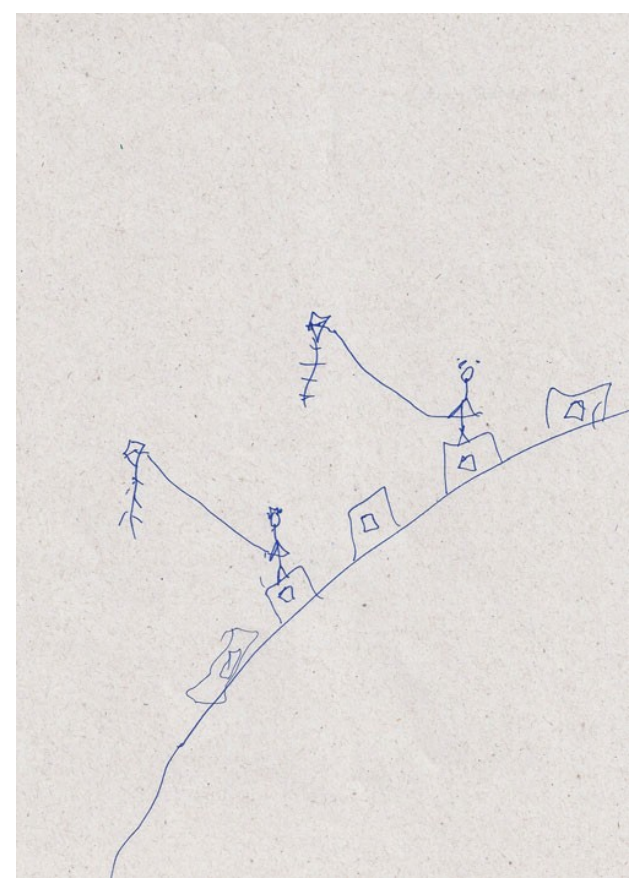


Figure 9. Pigs eating garbage in the favela, 2014.

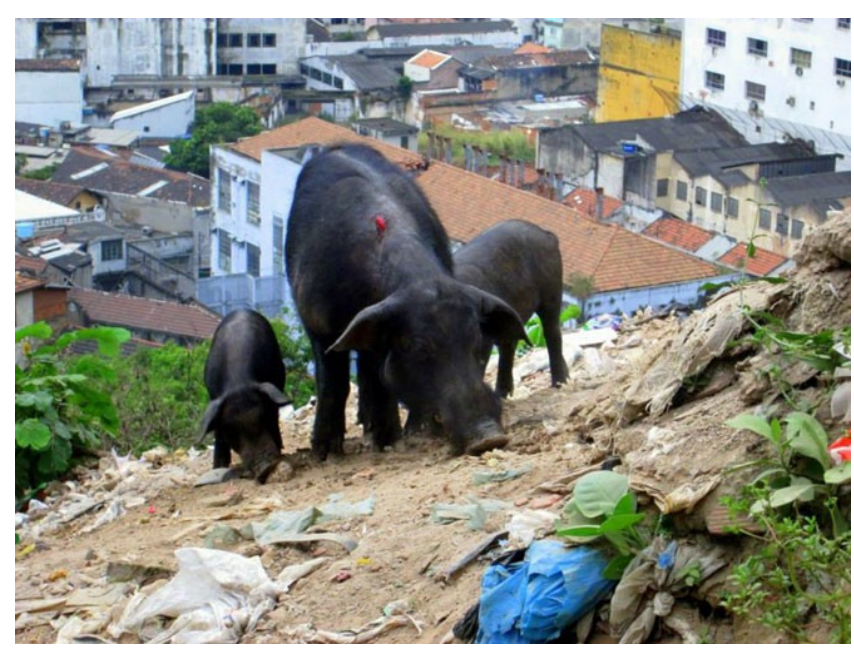

Source: the authors.

street." The lack of garbage bins contributes to trash littered walkways and alleyways despite hand-made signs throughout the community discouraging the practice. Rodnei, a 36-year-old man, born in Ceará but living in the favela since 2010, pointed out how the open sewers and poor garbage collection made the community vulnerable to rats and diseases. Alexandre, born in the favela 48 years before, explained that children "do not realize that when they throw garbage on the ground, it will not be cleaned up, and eventually they are playing barefoot in garbage and sewage." Several participants noted that the teleférico construction had worsened the sewage problem. As Bruno illustrated on his map in Figure 2, sewage flows from the manholes and down the cobblestone street, collects against the concrete pillar of the cable car, and coats it in a thick layer of green sludge. In total, 12 percent of the participants indicated the ill-functioning sewer system on their maps of the present, and nearly 30 percent of all the maps of a desired future referenced social programs to increase awareness concerning hygiene and trash disposal.

A third dominant theme involves access to food, with 40 percent of participants including a supermarket on their maps. Tania, 32-years-old, works at the only bakery (padaria) in the favela. Even though the bakery sells a variety of items, she says a supermarket in the favela is a "necessity" for two primary reasons. First, a local supermarket is necessary to ensure that the residents have access to a variety of fresh and canned foods. Second, the site of Morro da Providência on a hill means that residents are forced to laboriously carry everything up steep inclines. Tania's map therefore emphasizes the vertical dimension, showing the steepness of her walk from her house (casa) down to the padaria, and then to the supermarket 
Figure 10. Tania's map, 2013.

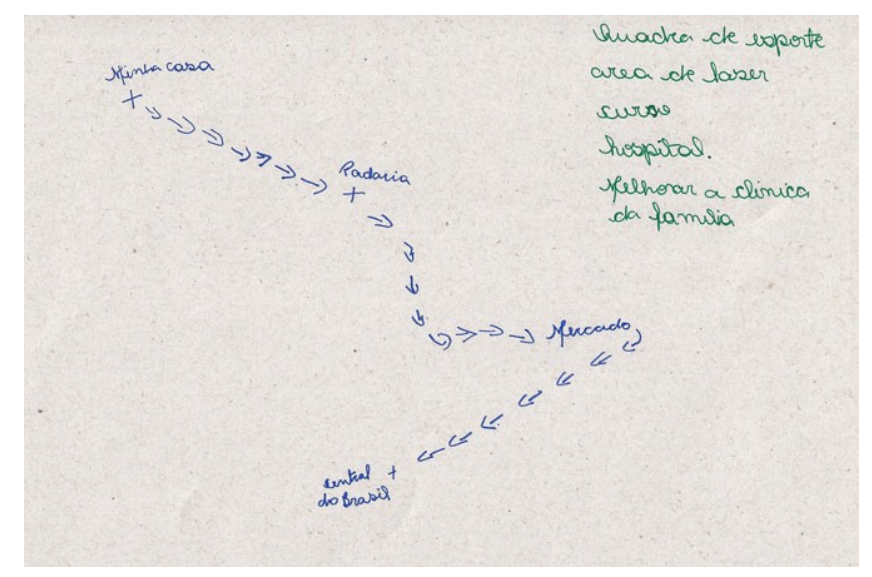

(mercado) about half-a-mile from the base of the favela (Figure 10). While a privately-owned van service (kombi) has one stop in the middle of the favela, it is often crowded, and has limited hours of operation. Going to the supermarket by kombi could take nearly forty minutes. And, once the residents arrive back in the favela, many must still carry their groceries either up or down steep staircases and through winding alleys to reach their homes in other parts of the favela (Figure 11). It should be mentioned that grocery delivery services do exist, but they are prohibitively expensive for most residents owing, in part, to the man-power necessary to handdeliver groceries in such steep terrain.

One more look at Tania's map will also underscore the significance of mental mapping as an effective methodology. Tania's mental map clearly depicts the verticality of Morro da Providência as the places of importance appear at different, descending elevations. The ability of mental mapping to capture elevation is an important dimension which is not always so easily represented by more conventional planar analyses. Tania also took the time to draw arrows to indicate the direction she must go to reach her places of importance, all of which, aside from her home, are places located outside of the community.

Transportation figured in the maps of twenty-four (40 percent) of the participants and forms the fourth major theme. In 2013, construction of the teleférico remained underway. The 665-meter aerial tram was designed to connect the newly renovated Cidade do Samba in the port area to the Central do Brasil Metro station and the SuperVia train station. The plans included sixteen gondolas with a capacity of up to 1,000 passengers per hour. The single station of the cable car system located in Morro da Providência was under construction in the middle of the favela and therefore to a point in the community also accessible by car and the kombi service. Beyond that point, the upper portions of the favela where a large 
Figure 11. Resident with groceries at the historic staircase, 2013.

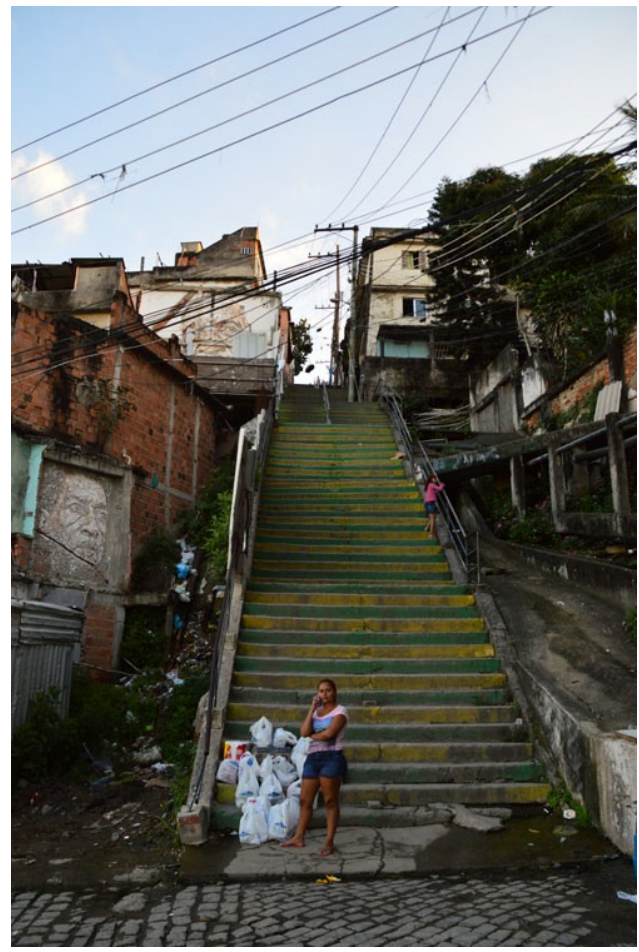

Source: by permission of Guilherme Dias da Fonseca.

number of residents live are accessible only by foot, with the main route up the hundred-and-sixty-five-step historic granite staircase. The Morar Carioca Project planned to overcome that accessibility issue by building a funicular tram parallel to one side of the staircase. However, that project would have required the removal of several historic homes and although the residents were largely in favor of the funicular tram, no one wanted to displace any of their neighbors. Echoing the sentiments of eighteen other participants, Júlio ventured that "it would be a shame for the city to remove all of the residents simply to complete another construction project." His map depicts the location of the funicular tram in green, indicating that it might be built in the future (Figure 12).

Some participants suggested alternatives to the teleférico and funicular tram, such as an escalator or elevator, to avoid the dilemma of evicting the residents and demolishing their houses to improve access for the remaining residents. Márcio, age 59, put forth the idea of having an elevator built that would extend from the bottom of an old quarry to the small plaza in the upper favela (Figure 13). The elevator would not only make the teleférico and funicular tram unnecessary, but it would also solve the 
Figure 12. Júlio's map showing the possible future funicular, 2013.

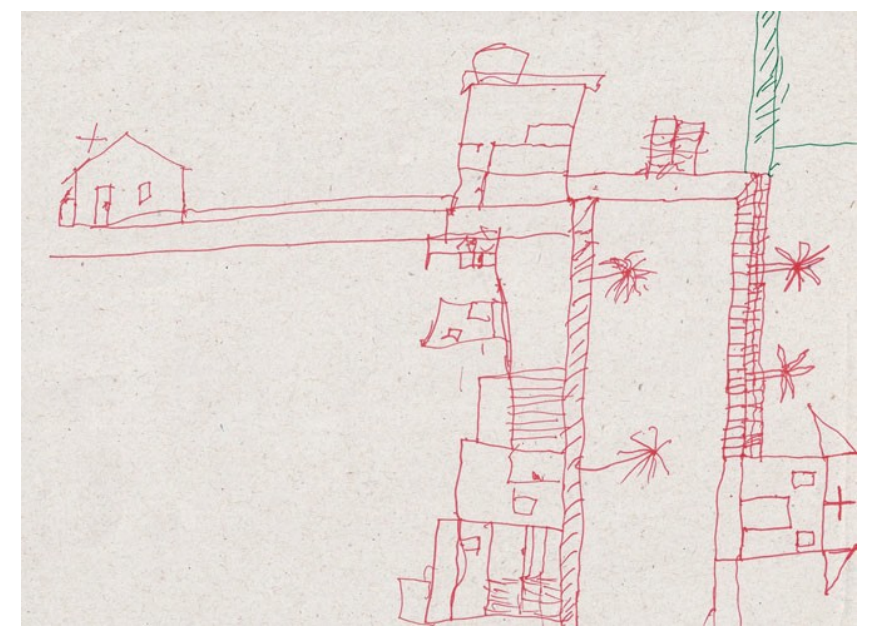

garbage removal problem. Márcio explained, "The elevator will have two parts. One part will be social, and the other part will be for trash." Carla, age 44, suggested that instead of the funicular tram, an escalator (escada rolante) could be built on top of the historic staircase, similarly negating the need to demolish houses or displace residents (Figure 14). Both transportation alternatives presented by the residents for either the elevator or escalator negated the removal of residents from their homes.

The fifth and final theme involves fear (medo) mentioned by 28 percent of the respondents. In Morro da Providência, the presence of fear was mentioned in two distinct ways. First, residents described being fearful due to the lack of information about the infrastructure projects. Not one participant the authors interviewed had been consulted in the Morar Carioca planning process. Consequently, when representatives from the Secretary of Municipal Housing entered the community and spray-painted houses to indicate their imminent removal - without talking to the residentswidespread fear and confusion resulted (Figure 15). Some residents believed their homes were marked for removal so that the city could build a luxury hotel in its place, while other residents were left wondering when they would have to vacate their homes and where they would go. During this Olympic exception, after all, residents in other favelas had indeed received such eviction notifications.

The second type of fear related to the city's motivation for and commitment to the teleférico as a transportation alternative. Residents believed that the teleférico was being constructed for the mega-event tourists and not for them, as claimed in the literature published by the city (Prefeitura 2012). This suspicion led the residents to question if the teleférico would receive sufficient funds for maintenance after the Olympics ended. 
Figure 13. Márcio's map showing the elevator in green, 2013.

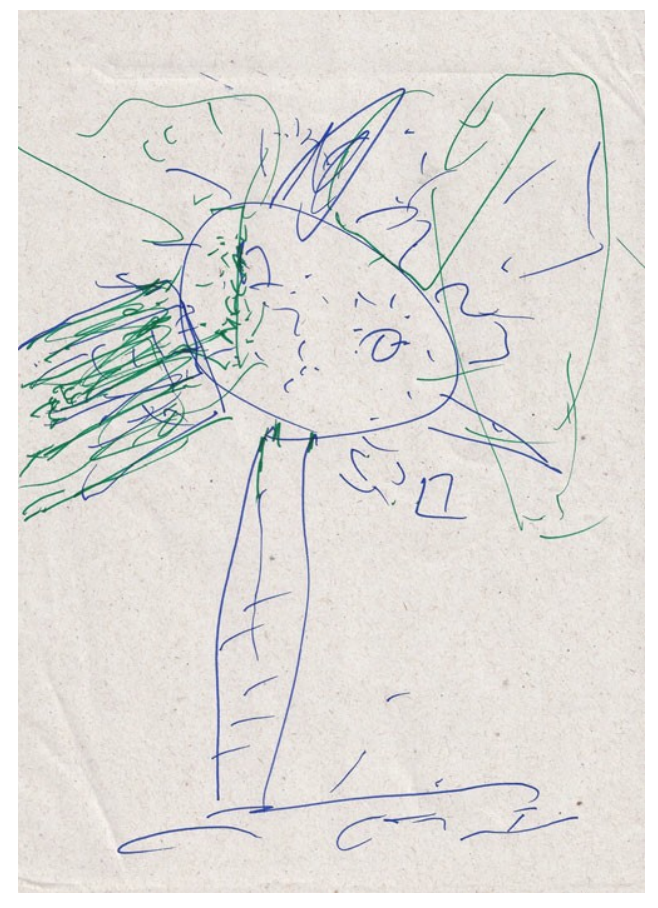

According to Daniel, age 23, "When the city does not have more money to finance the teleférico, they are going to abandon the project and then they will have removed the Praça Américo Brum for nothing." Many other residents echoed Daniel's concerns and firmly believed that the teleférico would fall into decay after the Olympics ended.

\section{From Mapping to Social Action}

The richly detailed mental maps and accompanying discussions with participants reveal their perspectives on how their marginalized urban space was undergoing intense transformation as the city government prepared for the 2014-2016 mega-events. The resulting analysis demonstrates how the conceived space of planners conflicts with the lived space of the favela residents regarding open public space, sanitation, food access, and transportation and how the lack of transparency results in fear.

In August 2013, the conflict between the production of conceived and lived spaces resulted in a court injunction to halt the infrastructure projects. A group comprised of residents and non-residents known as the Comitê Popular Rio Copa e Olimpíadas (Popular Committee of the Rio de Janeiro Cup and Olympics) working with the Public Defender's Office claimed that the Morar Carioca program was illegal because the community had not been involved in the planning process. According to the Comitê 
Figure 14. Carla's map showing the escalator in green, 2013.

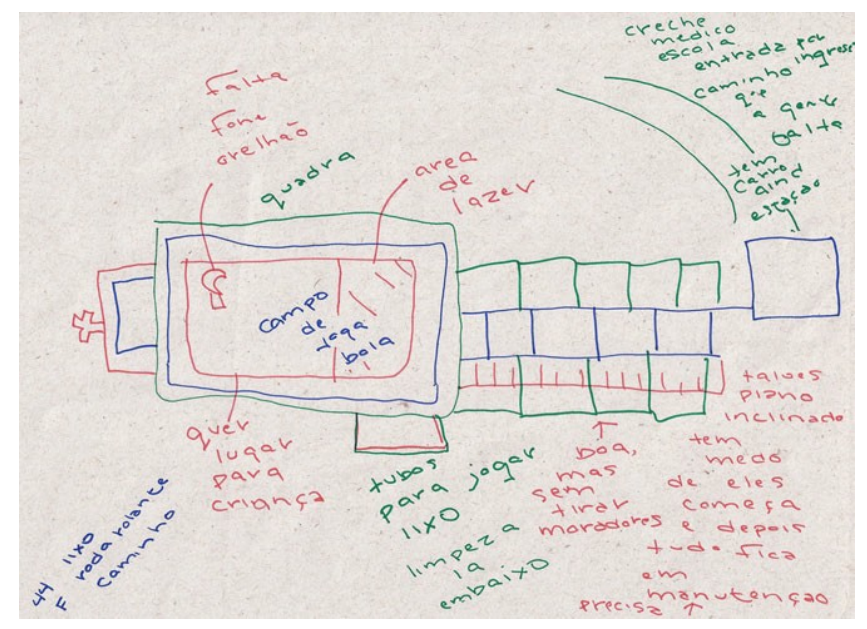

Figure 15. Resident in Front of her Home Marked for Removal. Photo taken by authors, 2013.

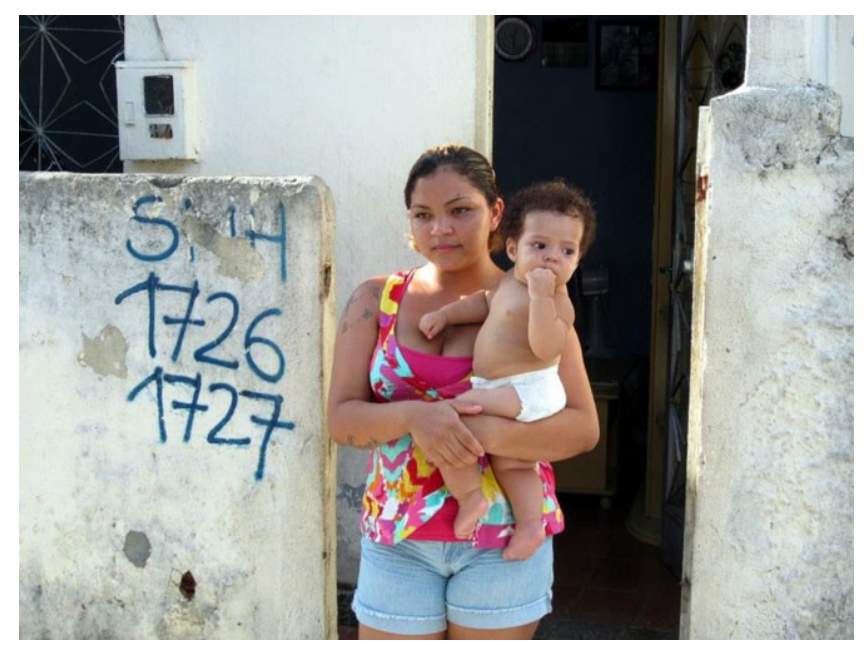

Popular, despite "the amount of resources and the impact of interventions in the city ... decisions regarding these investments did not undergo a broad democratic discussion, involving all segments of society, putting in question the design of the city" (Comitê Popular Rio Copa e Olimpíadas 2014,6). The court ruled that residents are lawfully entitled to participation in the planning of projects that impact their community, and the planning associated with the mega-events had been authoritarian and "contrary to the guidelines of the City Statute (Law 10257/2001)" (Comitê Popular Rio Copa e Olimpíadas 2014, 68). Moreover, the city neither performed the 
Environmental Impact Assessment study nor obtained a Neighborhood and Environmental Impact License, both required by law (Comitê Popular Rio Copa e Olimpíadas 2014, 29; Pontes and Magalhães 2013). The court thereby terminated all Morar Carioca projects in the community, including the funicular tram, the recreational plaza destined for the teleférico station, the sports center, sewer improvements, outdoor lighting, and street paving (Antunes 2013; Constancio 2014; Santos and Asevedo 2011). The homes of 800 families were saved. However, the city successfully argued that the equipment for the teleférico had been purchased before the injunction, and that the impact of that project was confined to one station and would not jeopardize the community. As such, construction continued and the teleférico was inaugurated on July 2, 2014 nearly fifteen months after its construction was complete. Its inauguration coincided with the World Cup matches, which had begun in mid-June and ended with the final in mid-July at the nearby Maracanã stadium.

To confirm the suspicions of the favela residents, as of the writing of this paper in 2018, the teleférico has been closed for well over a year. Just as the residents feared, the teleférico officially suspended service in December 2016. In follow-up interviews conducted in June 2018, community residents told the authors that they retained some hope that the teleférico service may be reinstated soon, but only because it is currently an election year. Transportation infrastructure provides a dramatic example of the wealth of resident ideas about infrastructure that could fit their lived space and contrasted markedly with the conceived space of the PPP projects. Márcio's idea for an elevator from the base of the favela to the small plaza in the upper favela and Carla's idea for an escalator instead of a funicular alongside the historic stairs have successful precedents elsewhere. In 2011, the city built an elevator that lifts people 64-meters from the General Osório Metro station to the Cantagalo and Pavão-Pavãozinho favelas (Marqueiro 2011). While no favela in Rio de Janeiro currently has an escalator, an outdoor escalator carries people up to the popular tourist attraction, Christ the Redeemer Statue located on Corcovado Mountain. Moreover, an outdoor escalator carries people up and down 385-meters to the Comuna 13 slum in Medellin, Columbia (Henley, 2013). Such innovative modes of transportation would also positively impact access to food and partially solve the issue of sanitation. If instead city planners had consulted favela residents and incorporated their detailed local knowledge and ideas conflict could have been reduced and the infrastructure projects completed in ways that harmonized lived space and conceived space. Emblematic of the complete disjunction between conceived space and lived space, construction workers had installed concrete planters in front of the teleférico station, but they sat empty. When Katrina, age 67, offered to donate plants from her garden to fill the planters as a way to help create open public spaces, the Odebrecht workers and city officials refused. "They would rather buy plants than accept ones that I grew here in the community," she complained. As she put it in the aftermath of the 
court order that stopped the infrastructure projects, "If they had asked us, we could have told them what we wanted."

\section{Works Cited}

Aberley, D. 1993. Boundaries of home: Mapping for local empowerment. Gabriola Island: New Society.

Agnew, J. 2011. "Chapter 23: Space and Place." In Handbook of Geographical Knowledge, by \& D. Livingstone J. Agnew, 1-34. London: Sage.

Anthony, C. G. 2013. "Urban Forced Removals in Rio de Janeiro and Los Angeles: North-South Similarities in Race and the City." International American Law Review 44 (2): 337-364.

Antunes, C. 2013. "Os discontentes do porto." Revista Piaui, May 27: 355376.

Arias, Desmond Enrique. 2008. "Faith in Our Neighbors: Networks and Sociel Order in Three Brazilian Favelas." Latin American Politics and Society, 1-38.

Arias, E. D. 2006. Drugs \& Democracy in Rio de Janeiro. Chapel Hill: The University of North Carolina Press.

Arias, E. D. 2004. "Faith in Our Neighbors: Networks and Social Order in Three Brazilian Favelas." Latin American Politics \& Society 46 (1): 1-38.

Bell, P., Greene, T., Fisher, J., \& Baum, A. 1996. Environmental Psychology. Orlando: Harcourt Brace College Publishers.

Carneiro, J. 2014. “Favela life: Rio's city within a city." BBC News. June 9. http://www.bbc.com/news/world-latin-america-27635554.

CDURP. 2017. "Companhia de Desenvolvimento Urbano da Região do Porto do Rio de Janeiro ." Porto Maravilha. 6. http:// portomaravilha.com.br/summary.

Constancio, Thaise. 2014. "A prefeitura do Rio inaugura o teleférico da Providência." Agencia Estadão. July 2. http://www.estadao.com.br/ noticias/geral,prefeitura-do-rio-inaugura-teleferico-da-providencia, 1522503.

Crang, M., \& I. Cook. 2007. Doing Ethnographies. London: Sage.

da Vinha, Luis. 2012. "Charting Geographical Mental Maps in Foreign Policy Analysis: A Literature Review." Human Geographies-Journal of Studies and Research in Human Geography 6 (1): 5-17.

DeWalt, K. M., \& DeWalt, B. R. 2002. Participant Observation: A Guide for Fieldworkers. New York: Alta Mira Press.

Elden, S. 2004. Understanding Henri Lefebvre: Theory and the Possible. London: Continuum.

Elwood, S. 2002. "GIS use in community planning: A multidimensional analysis of empowerment." Environment and Planning A 34: 905-22.

Elwood, S., \& Leitner, H. 1998. "GIS and community- based planning: Exploring the diversity of neighborhood perspectives and needs." Cartography and Geographic Information Systems 25 (2): 77-88. 
Fahy, F., \& Cinnéide, M. Ó. 2009. "Re-constructing the urban landscape through community mapping: an attractive prospect for sustainability?" Area 41, 167-175.

Gaffney, Christopher. 2016. "The Urban Impacts of the 2014 World Cup in Brazil." In Mega-Events and Globalization, by Richard Gruneau and John Horne, 167-185. New York: Routledge.

Galdo, Rafael. 2011. Rio é a cidade com maior população em favelas do Brasil. O Globo. Rio de Janeiro, December 21. http://oglobo.globo.com/.

Goldstein, D. M. 2003. Laughter Out of Place: Race, Class, Violence and Sexuality in a Rio Shantytown. Berkeley: University of California Press.

Golledge, R., \& Stimson, R. 1997. Spatial Behavior: A Geographic Perspective. New York: The Guilford Press.

Harley, J. B. 1991. "Can there be a cartographic ethics?" Cartographic Perspectives 10.

Harley, J. B. Cartographica. 1989. "Deconstructing the map." Cartographica 26 (2): 1-20.

Hayden, Dolores. 1995. The Power of Place: Urban Landscapes As Public History. Cambridge: The MIT Press.

Henley, J. 2013. "Medellín: the fast track from the slums." The Guardian: July 31. http://www.theguardian.com/world/2013/ jul/31/medellin-colombia-fast-track-slums-escalators.

Instituto Brasileiro de Geografia e Estatística (IBGE). 2010. “Censo 2010.” Instituto Brasileiro de Geografia e Estatística (IBGE). December 12. http://censo2010.ibge.gov.br/en/.

Kitchin, R., \& Freundschuh, S. 2000. Cognitive Mapping: Past, Present and Future. London: Routledge.

Kyem, P. 2004. "Power, Participation and inflexible institutions: An examination of the challenges to community empowerment in participatory GIS applications." Special issue. Cartographica 38 (3 \& 4): 5-17.

Larkins, Erika Robb. 2015. The Spectacular Favela: Violence in Modern Brazil. University of California Press.

Leeds, Elizabeth. 1996. "Cocaine and Parallel Polities in the Brazilian Urban Periphery." Latin American Research Review, 47-83.

Lefebvre, Henri. 1991. "Social Space." In The production of space., by Henri Lefebvre. Oxford: Blackwell.

- - - 2009. State, Space, World: Selected Essays. Minneapolis: University of Minnesota Press.

Lynch, K. 1960. The Image of the City. Cambridge: The MIT Press.

Mark, D. M. 1999. "Cognitive models of geographical space." International Journal of Geographical Information Science 13 (8): 747-774.

Marqueiro, P. 2011. "Elevador do Cantagalo fica pronto em junho." Oglobo. March 29. http:/ / oglobo.globo.com/rio/elevador-docantagalo-fica-pronto-em-junho-3033908. 
Mitchell, Gladys L., \& Bernd Reiter. 2010. Brazil's New Racial Politics. Boulder: Lynne Rienner Publishers, Inc.

Mollett, S. 2013. "Mapping Deception: The Politics of Mapping Miskito and Garifuna Space in Honduras." Annals of the Association of American Geographers 103 (5): 1227-1241.

Monmonier, M. 1991. How to lie with maps. Chicago: University of Chicago Press.

Moore, G., \& Golledge, R. 1976. "Envrionmental Knowing: Theories and Concepts. " In Envrionmental Knowing: Theories, Research and Methods, by \& R. Golledge G. Moore, 3-24. Stroudsburg: Dowden, Hutchinson, and Ross.

Neele, Bruno. 2012. "The U.S. Environmental Protection Agency." U.S.Brazil Joint Initiative on Sustainability, Morar Carioca: Integrating Informal Settlements. Accessed June 8, 2017. https:/ / archive.epa.gov/ international/jius/web/html/morar_carioca_integrating_informal_ settlements.html.

Novaes, Andre Reyes. 2014. "Favelas and the divided city: mapping silences and calculations in Rio de Janeiro's journalistic cartography." Social \& Cultural Geography 15 (2): 201-225.

Odebrecht. 2011. “The First PPP for Urban Revitalization." Odebrecht. January 13. http://odebrecht.com/en/first-ppp-urban-revitalization.

Olimpíadas, Comitê Popular Rio Copa e. n.d. “Megaeventos e Violações dos Direitos Humanos no Rio de Janeiro Dossiê."

Oosterbaan, Sarah, \& Joris van Wijk. 2015. "Pacifying and integrating the favelas of Rio de Janeiro: An evaluation of the impact of the UPP program on favela residents." International Journal of Comparative and Applied Criminal Justice 39 (3): 179-198.

Perkins, C. 2007. "Community Mapping." The Cartographic Journal 44 (2): 127-137.

Perlman, Janice. 2010. Favela: Four Decades of Living on the Edge in Rio de Janeiro. Oxford: Oxford University Press.

- - - 1976. The Myth of Marginality: Urban Poverty and Politics in Rio de Janeiro. Berkeley: University of California Press.

Pocock, D. C. 1976. “Some Characteristics of Mental Maps: An Empirical Study." Transactions of the Institute of British Geographers, New Series 4 (4): 493-512.

Pontes, F., \& Magalhães, L. E. 2013. "Providência vira um grande canteiro de obras abandonado: Briga judicial entre moradores e prefeitura paralisa urbanização." Oglobo. July 9. http://oglobo.globo.com/rio/ providencia-vira-um-grande-canteiro-de-obras-abandonado-9872055.

Prefeitura do Rio de Janeiro. 2012. Projectos de Integração: Uma Cidade Para Todos. Rio de Janeiro. Rio de Janeiro: Prefeitura do Rio de Janeiro.

Roberts, Adam. 2000. "Cognitive Mapping." In Routledge Critical Thinkers, by Fredric Jameson, 141-142. Taylor \& Francis Ltd.

Rose, G. 2003. "Family photographs and domestic spacings: a case study." Transactions 28 (1): 5-18. 
Saarinen, T. 1987. Centering of Mental Maps of the World. Tuscon: University of Arizona.

Santos, M. C., \& Asevedo, M. d. 2014. "Relatório Morro da Providência/Pedra Lisa." DropBox. May 22. https://dl.dropboxuser content.com/u/24554646/Relat\%C3\%B3rio\%20Morro\%20da\%20Pro vid\%C3\%AAncia_final.pdf.

Sieber, R. E. 2001. "A PPGIScience?" Special issue. Cartographica 38 (3 \& 4): $1-4$.

Soini, K. 2001. "Exploring human dimensions of multifunctional landscapes through mapping and map making." Landscape and Urban Planning 225-239.

Spinetto, J. P. (2014, June 18). Retrieved June 20, 2014, from. 2014. "World Cup Fans Embrace Brazilian Party in Rio's Top Slum." Bloomburg Businessweek. June 18. Accessed June 20, 2014. http://mobile. businessweek.com/news/2014-06-18/world-cup-fans-embrace-brazi lian-party-in-rio-s-top-slum.

Tolia-Kelly, D. 2004. "Locating processes of identification: studying the precipitates of rememory through artefacts in the British Asian home." Transactions, 29: 314-329.

Tolman, E. 1948. "Cognitive Maps in Rats and Men." The Psychological Review 55 (4): 189-208.

Vargas, J. C. 2003. “Race \& Class.” Institute of Race Relations 44 (4): 19-40.

Williamson, Theresa. 2017. "Rio's Favelas: The Power of Informal Urbanism." In Perspectiva: Urban Divides, by Meghan MCallister and Mahdi Sabbagh, 213-228. Cambridge: MIT Press.

Williamson, Theresa, \& Mauricio Hora. 2012. "In the Name of the Future, Rio Is Destroying Its Past." New York Times. August 12. Accessed June 5, 2014. http://www.nytimes.com/2012/08/13/opinion/in-thename-of-the-future-rio-is-destroying-its-past.html?gwh=10B4B0E02D 150FBD869575FB71F4B701\&gwt=pay\&assetType=opinion.

Wood, D. 1992. The power of maps. New York: Guilford. 